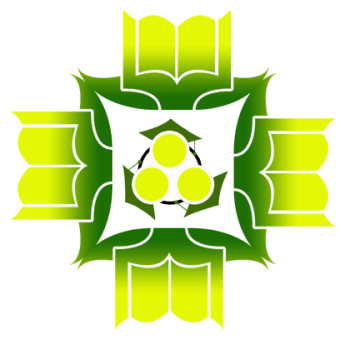

\title{
PROBLEM SOLVING ABILITY ANALYSIS ASSESSED FROM SELF-EFFICACY IN THE MISSOURI MATHEMATICS PROJECT LEARNING MODEL
}

\author{
Zulmi Roestika Rini \\ Universitas Ngudi Waluyo \\ zulmiroestikarini@unw.ac.id \\ Kartika Yuni Purwanti \\ Universitas Ngudi Waluyo \\ kartikayunipurwanti@unw.ac.id
}

\begin{abstract}
Abstrack
This study has purposes, namely to test the effectiveness of the MMP learning model on problem-solving abilities and to describe problem solving abilities in terms of self-efficacy. The benefits of this research are (1) Students get meaningful knowledge to develop problem-solving skills through the MMP learning model (2) Teachers can choose the right learning model to develop problem solving abilities (3) Provide an overview to the teachers about problem solving abilities in terms of self-assessing student's efficacy. The results showed that: (1) the MMP learning model was effective on problem solving abilities, (2) a) high self-efficacy' students could understand problems, plan problem-solving, and implement problemsolving plans, as well as re-examine correctly and completely. b) moderate self-efficacy's students could understand problems, plan problem-solving, implement problem-solving's plan correctly but not yet completely, re-examine but not yet able to use other methods. c) low self-efficacy's students could understand problems and plan problem-solving correctly but incompletely, less able to carry out problem-solving plans, but unable to re-examine and use other methods. Based on data and research findings regarding problem-solving abilities in terms of student self-efficacy in MMP learning, it can be recommended: (1) Teachers should guide and help developing the low self-efficacy's students problem-solving abilities to further improve their abilities. (2) Measuring the students' self-efficacy
\end{abstract}


even involving a psychological institution in every school is important, so that each school has self-efficacy's data to provide treatment to the students. (3) The low self-efficacy's students need further treatment by cultivating confidence and giving direction that they are able to learn mathematics, improving problem solving skill and not prioritizing memorization in learning mathematics.

Keywords: Problem solving skill, Missouri Mathematics Project, SelfEfficacy.

\begin{abstract}
Penelitian ini memiliki tujuan yaitu untuk menguji keefektifan model pembelajaran MMP terhadap kemampuan pemecahan masalah dan mampu mendeskripsikan kemampuan pemecahan masalah yang ditinjau dari selfefficacy. Manfaat peneletian ini adalah (1) Siswa memperoleh pembelajaran bermakna guna mengembangkan kemampuan pemecahan masalah melalui model pembelajaran MMP (2) Guru dapat memilih model pembelajaran yang tepat untuk mengembangkan kemampuan pemecahan masalah (3) Memberikan gambaran kepada guru tentang kemampuan pemecahan masalah ditinjau dari self-efficacy siswa. Hasil penelitian menunjukkan bahwa: (1) model pembelajaran MMP efektif terhadap kemampuan pemecahan masalah, (2) a) siswa yang memiliki selfefficacy tinggi mampu memahami masalah, merencanakan pemecahan masalah, dan melaksanakan rencana pemecahan masalah, serta memeriksa kembali dengan benar dan lengkap, b) siswa yang memiliki self-efficacy sedang mampu memahami masalah, merencanakan pemecahan masalah, melaksanakan rencana pemecahan masalah dengan benar tapi belum lengkap, memeriksa kembali belum mampu menggunakan cara lain, dan c) siswa yang memiliki self-efficacy rendah mampu memahami masalah dan merencanakan pemecahan masalah dengan benar namun kurang lengkap, kurang mampu dalam melaksanakan rencana pemecahan masalah, tetapi tidak mampu memeriksadan menggunakan cara lain. Berdasarkan data dan temuan penelitian mengenai kemampuan pemecahan masalah yang ditinjau dari self-efficacy siswa pada pembelajaran MMP, dapat direkomendasikan: (1) Guru hendaknya membimbing dan membantu mengembangkan kemampuan pemecahan masalah siswa yang mempunyai self-efficacy rendah agar semakin meningkatkan lagi kemampuannya. (2) Penting dilakukan pengukuran self-efficacy siswa di setiap sekolah yang melibatkan lembaga psikologi agar setiap sekolah mempunyai data self-efficacy sehingga dapat memberikan penanganan kepada siswa. (3) Perlu penanganan lebih lanjut bagi siswa yang memiliki self-efficacy rendah, dengan menanamkan rasa percaya diri dan arahan bahwa mereka mampu untuk belajar matematika, membimbing siswa dengan memberikan soal pemecahan masalah serta tidak mengutamakan hafalan dalam pembelajaran matematika.
\end{abstract}

Kata Kunci: Keterampilan Pemecahan Masalah, Proyek Matematika Missouri, Efikasi Diri. 


\section{INTRODUCTION}

HOTS (Higher Order Thinking Skill) or what is often called as the ability of higher order thinking skills or concepts is a concept of educational reform based on Bloom's taxonomy began in the early 21st century. This concept included in education aims to prepare resources human resources in the face of the industrial revolution. In this 21st century human resources are expected not only to be workers who follow the government, but have 21st century skills. according to Abduhzen in Faddilah (2019) HOTS is not a subject, nor is it a matter of the final goal of the exam that is achieved through the approach, learning processes and methods. HOTS (Higher Order Thinking Skills) skills are a thought process which requires students to develop ideas in a which gives them new meanings and implications. Higher Order Thinking involves critical thinking and creatively guided by the ideas of their respective truths have meaning. Critical and creative thinking are interdependent, as well as criteria and values, reason and emotion. Higher order thinking skills are cognitive operations that are much needed in thinking processes that consist of short-term memory. If it is associated with Bloom's taxonomy, higher order thinking includes analysis, synthesis, and evaluation. In addition, that high-order thinking skills (High Order Thinking) are much more needed today than in previous times. From the above definitions, it can be concluded that HOTS (High Order Thinking Skills) are higher-order thinking skills that must be present in students who do not only test intellectual abilities in terms of memory but also test the ability to evaluate, create, analyze and think critically about students' understanding of a subject and put more emphasis on critical thinking towards a problem solving. So higher-order thinking skills are not only tested on the skills of memorizing a subject matter but rather on the application. One of the high-level skills is problem-solving.

Problem solving is one of the most valuable aspects of mathematics education (Tzohar \& Kramarski, 2014). Polya (1985) defines problem solving as an attempt to find a way out of a difficulty in order to achieve a goal that is not immediately attainable. Ganieh in Paul (2014) reveals that problem solving is the highest form of learning and the type of process that students use to be able to find new combinations of what they have learned previously to find ways to solve new problems. According to Abdurrahman in Dwiningrat et al (2014) 
problem solving is the application and concept of skills. The problem-solving ability used in this study refers to the stages of Polya (1985). These stages include: (1) understanding the problem includes writing what is known, the question asked, and a description / sketch of the problem. (2) Planning problem solving by estimating the steps or formulas that will be used in problem solving. (3) Implementing the problem-solving plan by solving the problem using the steps or formulas that have been selected or determined. (4) Reexamining the results of problem solving includes checking the correctness of the results at each step taken in problem solving and solving problems with different steps.

From the stages of problem solving put forward by Polya, the problemsolving indicators in this study can be seen in table 1 .

Table 1 Problem Solving Indicators Based on Polya's Problem Solving Stages

\begin{tabular}{|c|c|c|}
\hline No. & Polya's Problem Solving Stage & Indicator \\
\hline \multirow[t]{3}{*}{1.} & \multirow[t]{3}{*}{ Understand the problem } & Write down what is known \\
\hline & & Write down what was asked \\
\hline & & Write a picture / sketch of the problem \\
\hline 2. & Planning for problem solving & $\begin{array}{l}\text { Develop a problem-solving plan Estimating } \\
\text { the formula that will be used in problem } \\
\text { solving }\end{array}$ \\
\hline \multirow{2}{*}{3.} & \multirow{2}{*}{$\begin{array}{l}\text { Carry out a problem-solving } \\
\text { plan }\end{array}$} & $\begin{array}{l}\text { Solve problems with a plan / strategy that has } \\
\text { been selected / determined }\end{array}$ \\
\hline & & $\begin{array}{l}\text { Take decisions and actions by defining and } \\
\text { communicating final conclusions }\end{array}$ \\
\hline 4 & $\begin{array}{l}\text { Re-check the problem-solving } \\
\text { results }\end{array}$ & $\begin{array}{l}\text { Checking the correctness of the results at each } \\
\text { step carried out in problem solving }\end{array}$ \\
\hline
\end{tabular}

The learning model is a pattern or conceptual framework that describes systematic procedures in organizing learning experiences to achieve learning objectives (Suprijono, 2010). One of the learning models that can be applied in learning mathematics is the MMP model. Missouri Mathematics Project (MMP) is a mathematics learning model implemented in Missouri, a state of the United 
States of America under the Missouri Department of Primary and Secondary Education. Good and Grows (1979), suggest that MMP is focused on how teacher behavior influences student achievement, thereby following the product-process paradigm. The MMP learning model is one of the structured learning models like the Mathematics Learning Structure (SPM), but MMP has progressed with wellstructured steps. According to Krismanto (2003), in simple terms, the activity stages in the mathematics learning structure are as follows.

(1) Introduction, activities include perception, motivation and explanation of learning objectives.

(2) Development, activities include learning concepts or principles.

(3) Application, its activities include training in the use of concepts or principles.

(4) Closing, the activities include preparing a summary and assigning homework assignments (PR).

According to Widdiharto (2004), the advantages of the MMP model are: (1) The amount of material that can be delivered to students; Because it does not take too much time, time management can be regulated relatively tight. (2) The number of exercises; students are easily skilled with various questions. In addition, the MMP learning model is also effective in problem solving abilities. The research results by Savitri et al (2013) shows that the problem-solving ability of mathematics' students refer to the classically complete MMP, in which the average problem-solving ability of experimental class students is higher than the average problem-solving ability of control class students, and the average student activity in the experimental class was higher than the average activity of the control class students. Thus, as revealed by the research of Fauziah \& Sukasno (2015), it shows that the MMP model has a significant effect on students' mathematical problem-solving abilities.

Learning theories that support this research are Vygotsky's theory, Ausubel's theory, and Bandura's theory. Vygotsky's theory is one of the important theories in developmental psychology. Vygotsky's theory emphasizes the social aspects of learning. According to Vygotsky, learning occurs when children work or learn to handle unlearned tasks but those tasks are still within their reach or these tasks 
are in the zone of proximal development. A zone of proximal development is a development that is slightly above one's current development. The correlation between Vygotsky's theory and this research is that Vygotsky's theory supports cooperative work activities in MMP learning. In this activity, peer tutors were developed to help friends in the group who have difficulty learning and understanding the material. In addition, Vygotsky's theory of proximal development (Zone of Proximal Development) is also suitable for independent training. Independent training serves to deepen students' knowledge with tasks that are more level but still at one level of actual development.

Conventional learning is teacher-centered learning. According to what Sagala (2005) stated, conventional learning tends to place students in a passive position. Another feature of conventional learning is that students do two activities, namely listening and taking notes. In the Big Indonesian Dictionary, it is stated that "conventional is traditional". Furthermore, traditional is defined as "attitudes and ways of thinking and acting that are always upholding the norms and customs that have been passed down from generation to generation". Therefore, conventional models can also be referred to as traditional models. From the above understanding, it is concluded that the conventional model is a learning process in which the teaching and learning process is carried out in the old way, in delivering the lessons the teacher still relies on lecturing.

The conventional learning model is a learning model commonly used by teachers in teaching. The teacher is considered the center of education, while students only passively accept it without playing an active role in seeking information as a comparison of what the teacher says and as material to complement teacher references. This learning model is often identified with the lecture model; this is because conventional learning models generally consist of explanation of the material (lectures), question and answer, and assignments (Marnoko, 2011). Conventional learning usually applied in class V elementary Lab-School UNNES Semarang is individual learning. The teacher begins the lesson by motivating students, explains the material with several sample questions, allows the students to ask questions, provides individual exercises, asks several students to do the exercises in front of the class, asks the students to take note, and, at the end of the lesson, concludes the material. 
In learning activities, self-efficacy makes students choose to do or avoid a learning activity. Self-efficacy has mixed effects on a variety of motivational outcomes related to student engagement, including task choice, effort, and persistence (Pajares, 1996). Schunk (1981) states that a person's self-efficacy is classified into high self-efficacy and low self-efficacy. Students having high selfefficacy, were they given an assignment, they will enthusiastically / try hard to show their ability to achieve success. On the other hand, if the students do not have high self-efficacy, they tend to avoid assignments or carry them out halfheartedly so they will quickly give up when they encounter obstacles. Based on the definitions above, it can be deduced that self-efficacy is an individual's belief regarding his or her ability to organize, perform a task, achieve a goal, produce something and implement actions to display certain skills.

Lunenburg's research (2011) shows that self-efficacy affects the desire to learn and determines the goals a person wants to achieve. The results of Collins' research in Mukhid (2009) show that students who have mathematical abilities and have stronger self-efficacy, are faster in making strategies and solving problems, and choose to rework problems that they have not solved and do it more accurately than students. With the same ability whose self-efficacy is doubtful. The results of this study differ from the opinion of Pajares and Milles (Michaelides, 2009) who have researched to find that students who have high self-efficacy are not necessarily able to solve problem solving problems.

Schunk \& Hanson (1985) examined how students' self-efficacy and achievement were affected by their observations of the peer model. The results of these studies indicate that both the peer model and the teacher model produce higher self-efficacy and achievement than the control group who does not observe the model at all. The peer model has a higher impact on self-efficacy and achievement than the teacher model. Research conducted by McCoach (2007) shows that there is a significant increase in self-efficacy with changes in the instructional style of teachers in the learning process, namely through training and effort.

Collins in Mukhidi (2009) states that students with higher mathematical ability and self-efficacy are faster at making strategies and solving problems, and choose to rework problems they have not solved and do so more accurately than 
students with the same ability whose self-efficacy is doubtful. One of the efforts that can be made to grow self-efficacy is to actively involve students in cooperative learning. Cooperative learning in this study is intended so that students who have low self-efficacy will learn from the experiences of other students who have higher self-efficacy. The MMP learning model is a cooperative learning model that is thought to help develop students' problem-solving abilities and self-efficacy. In the MMP learning model, students are given group and independent exercises to develop a mathematical idea or concept so that students are trained in solving problems well. Furthermore, problem-solving abilities will be analyzed based on various levels of self-efficacy (high, medium, and low).

The success and failure of learning objectives originate from the effectiveness of learning in the classroom. During learning, the teacher plays an important role in making learning quality and optimal so that the students master their abilities. The quality of learning can be obtained from the strategies, approaches, models, and assessment instruments used during the learning process (Noor, 2020). Improving mathematics-learning quality can be done through applying appropriate learning models and interesting learning steps. Basic education, as part of the national education level, has a significant role in starting this character education. Cultivating character from an early age at stake for the future of our nation. Although measuring it carefully takes a long time, considering that educational products are certainly not only related to issues of value and passing (Mustaqim, 2015). There are many types of characters, one of which is self-efficacy. Bandura (2002) uses the term self-efficacy to refer to beliefs about a person's ability to organize and carry out actions to achieve certain goals. Bandura in Nicolaidou \& Philippou (2004) defines self-efficacy as a person's judgment on his ability to plan and carry out actions that lead to the achievement of certain goals / results. Pajares and Miller in Michaelides (2008) justify how confident he is to solve problem solving questions.

Based on the observations of the students in grade V elementary Lab-School Semarang, mostly the students solve problems' ability is still low. This can be seen when the students are given problem-solving questions in building materials. As many as 15 students out of 30 had difficulty working on the question and scored below the minimum criteria (KKM) score of 70. In addition, some students relied 
more on the answers of friends who were considered more capable of solving these questions. This is because the students feel unsure or doubt about their abilities. Success in learning is influenced by two factors, namely internal factors and external factors. Internal factors include physiological factors and psychological factors. According to Azwar (2008), physiological factors include the condition of the five senses and general physical conditions, while psychological factors include non-cognitive variables including interests, motivation, and personality, as well as cognitive variables including talent and intelligence. External factors include (1) physical factors such as learning places, learning facilities and equipment, subject matter and learning environment conditions, and (2) social factors, including social support and cultural influences. These conditions affect a person's success in learning, therefore to get optimal learning outcomes; these factors need to be prepared optimally. Especially for physical factors such as the learning environment, the learning model is one of the important factors that determine student success in learning.

The learning model plays an important role in the success of learning. One of the appropriate models to help develop students' problem-solving abilities and self-efficacy is the Missouri Mathematics Project (MMP) learning model. The students' cooperation and independence in the MMP learning model are highly emphasized. Good \& Grows (1979) defines MMP as a program designed to assist teachers in the effective use of exercises so that students achieve extraordinary improvements. The formulation of the problem in this study was (1) whether the MMP learning model was effective against the problem-solving abilities of students in class V elementary Lab-School Semarang and (2) how were the problem-solving abilities of students who had high, medium, and low selfefficacy. This study aims to (1) determine the effectiveness of the MMP learning model on students' problem-solving abilities and (2) describe the problemsolving abilities of students who have high, medium, and low self-efficacy.

\section{METHODS}

The method used in this research is the mixing method. The combination design used in this study is a concurrent embedded type. The combination method or concurrent embedded design (unbalanced mixture) is a research 
method that combines qualitative and quantitative research methods by mixing the two methods unequally (Sugiyono, 2013). The population of this study was the fifth grader of elementary Lab-School UNNES Semarang in the school year of 2019/2020. Two classes from the fifth grade classes in elementary Lab-School UNNES Semarang were randomly selected as the research sample. Thus, cluster random sampling was administered to determine the quantitative research sample. It is revealed that the VA class is the experimental class and the VB class is the control class. Meanwhile, research subjects focused for qualitative research are the VA class, namely the class subject to MMP learning. In this study, 6 students were taken as research subjects based on various levels of self-efficacy, consisting of 2 students with high self-efficacy, 2 students with moderate selfefficacy, and 2 students with low self-efficacy.

The research instrument used should be by the planned objectives. In this study, the instruments used to obtain the data used were: Self-Efficacy Inventory Sheet, Self-Efficacy Observation Sheet, and Problem-Solving Ability Test. The selfefficacy questionnaire sheet was used to measure the level of self-efficacy of each student. The indicators used in the preparation of the self-efficacy questionnaire in this study refer to the dimensions of self-efficacy proposed by Bandura (1997), namely magnitude, strength, and generality. The self-efficacy observation sheet is used to observe students' self-efficacy behavior during the learning process with the MMP learning model. The observations made are direct observation, that is, researchers directly observe students' self-efficacy behavior during the learning process.

The test questions used to measure students' problem-solving abilities are in the form of description questions. The preparation of the test instruments was carried out through several steps consisting of (1) limiting the material being tested; (2) determining the form of questions in the form of description questions; (3) determining the number of items; (4) determining the allocation of processing time; (5) creating question grids based on the applicable curriculum and learning objectives; (6) preparing question items along with answer keys and scoring guidelines; (7) testing research instruments in a predetermined trial class; (8) analyzing the results of the trial includes the level of difficulty, difference power, reliability and validity; and (9) selecting appropriate items based on the analysis that has been done. 
Data on students' problem-solving abilities in the initial conditions were obtained from a valid and reliable pretest of problem-solving abilities. A total of 30 students in class VA determined their self-efficacy based on the self-efficacy inventory score before learning. During learning, self-efficacy observations were carried out on research subjects. Students' answers to the problem-solving ability test (TKPM) were analyzed, then the research subjects were interviewed as triangulation. The quantitative data were tested using the normality test, homogeneity test, mastery test, and average difference test. Meanwhile, qualitative data analysis was done by reducing data, presenting data, drawing conclusions from the data that has been collected, and verifying these conclusions. This section explains how the research was carried out, which includes research designs, populations, and samples (research targets), data collection techniques, and data analysis techniques. For qualitative research such as classroom action research, case studies, and so on, it is necessary to add the presence of researchers, research subjects, informants who helped along with ways to explore research data, location, and duration of research as well as a description of checking the validity of research results.

\section{RESULTS AND DISCUSSION}

\section{Quantitative Data Analysis Problem Solving Ability Test}

The problem-solving ability test (TKPM) in this study is a test used to determine students' problem-solving abilities in distance material in threedimensional space. The average TKPM value for the experimental class and control class is presented in the following figure.

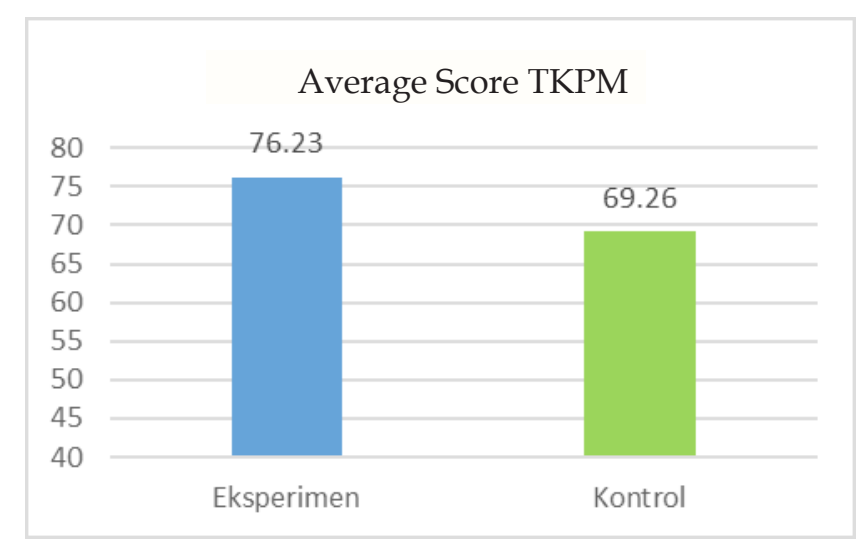

Graph 1 Average TKPM value 
Based on the results of the calculation of learning completeness in the experimental class using the proportion test, it was found that $z_{-}$count $=1.78$. At $a=5 \%, z$ table $=z_{-}((0.5-0.05))=z_{-} 0.45=1.64$. Because $z_{-}$count $>z_{-}$table, $\mathrm{H} 1$ is accepted. Therefore, it assumed that the problem-solving ability of the experimental class students who have reached the minimum completeness criteria, namely 70 , reaches more than $75 \%$. Based on the results of the calculation of the average difference test results of the problem-solving ability, it is obtained $t \_$count $=2.867$. The real level of $5 \%$ and $d k=66$ obtained $t$ table $=1.997$. Because $\mathrm{t}$ _count $>\mathrm{t}$ table, H0 is rejected. Hence, it can be concluded that the problemsolving ability of the experimental class students is higher than the students in the control class are.

The MMP learning model is effective against students' problem-solving abilities. This is because (1) the percentage of students in MMP learning reached completeness, scored of 70 , is more than $75 \%$; (2) the average result of TKPM measuring the problem-solving ability of students subjected to MMP learning is better than the students subjected to the conventional learning is. The results of this study are in line with the results of research by (Dwiningrat et al 2014) which showed that the average problem-solving ability of the students taught using the MMP learning model was better than the average student taught by conventional learning was. This shows a difference in problem-solving abilities between the two groups.

\section{Qualitative Data Analysis of Problem-Solving Ability in terms of Student Self- Efficacy}

At the stage of understanding the problem, the students having high selfefficacy problem solving abilities can understand the problem by explaining what is known, asking, and sketching pictures correctly and completely. Meanwhile, at the planning stage of problem solving, the students can plan a complete problem solving by drawing, explaining steps, and writing formulas that will be used correctly and completely. The following is an example of the student's work results with high self-efficacy in implementing problem-solving plans. 


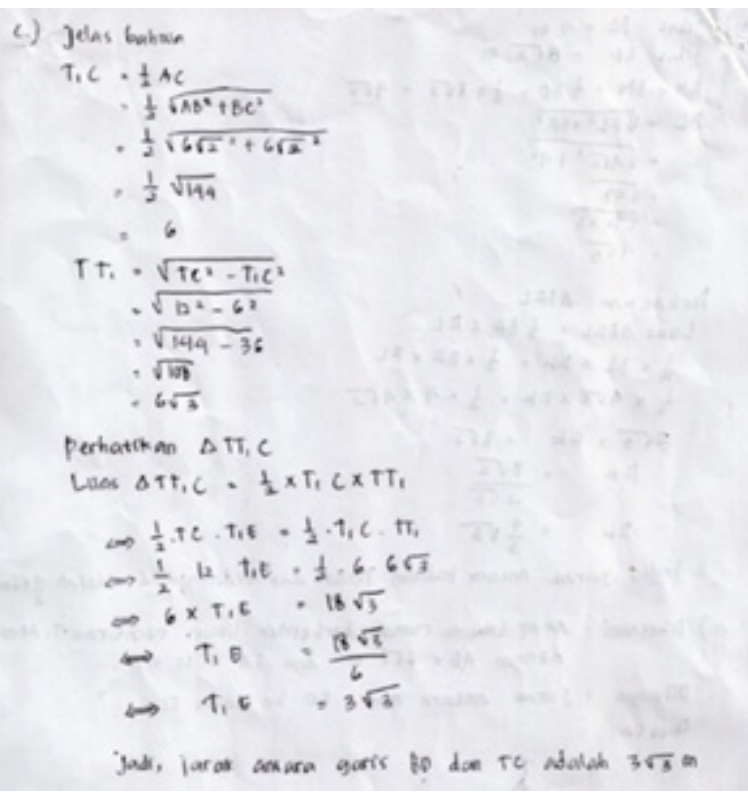

Figure 3. Examples of Student Work Results with High Self-Efficacy in Implementing Problem Solving Plan Problem Number 5 C.

The results of E-14's work in implementing the problem-solving plan for question number 5 can be seen in Figure 3. The figure shows that the E-14 can perform calculations according to the plan that was prepared previously and is correct in the calculations. E-14 can also write down the conclusion at this stage because E-14 believes that the answer is correct. At the stage of implementing the problem-solving plan, being able to carry out the problem-solving plan according to the plan, being able to perform calculations, and writing the final conclusion correctly and completely. At the re-examination stage, students who have high self-efficacy are able to re-examine by counting backwards, researching/rereading the steps taken and writing conclusions correctly and able to use other methods.

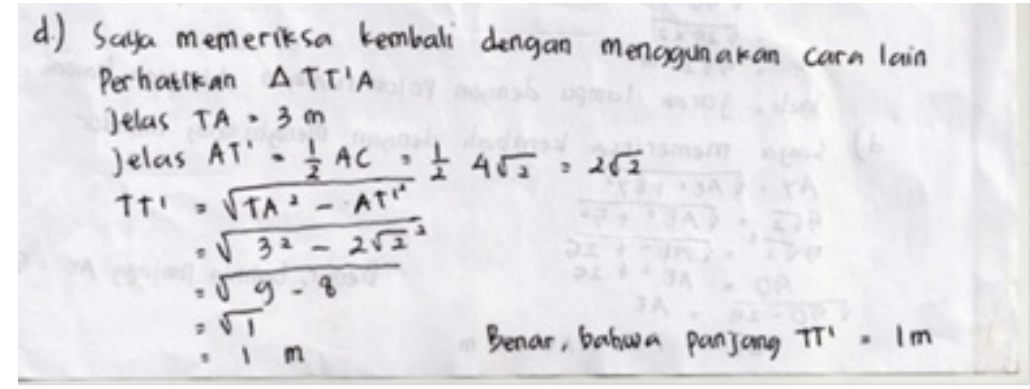

Figure 4. Examples of Student Work Results with High Self-Efficacy in Implementing Problem-Solving Plan Problem Number 4D. 
In Figure 4, E-14 re-examines question number $4 \mathrm{D}$ using another method so that E-14 is more sure that the answer obtained is correct. The problem-solving ability of students with moderate self-efficacy at the stage of understanding the problem is able to understand the problem by explaining what is known, asked, and able to sketch pictures correctly and completely. At the planning stage of problem solving, being able to plan problem solving by drawing, explaining the steps, and writing down the formula that will be used correctly and completely. At the stage of implementing the problem-solving plan, being able to carry out the problem-solving plan in accordance with, being able to perform calculations, and assuming plans correctly but incompletely. At the re-checking stage, students who have moderate self-efficacy are able to re-check by researching/rereading the steps taken but cannot use other methods.

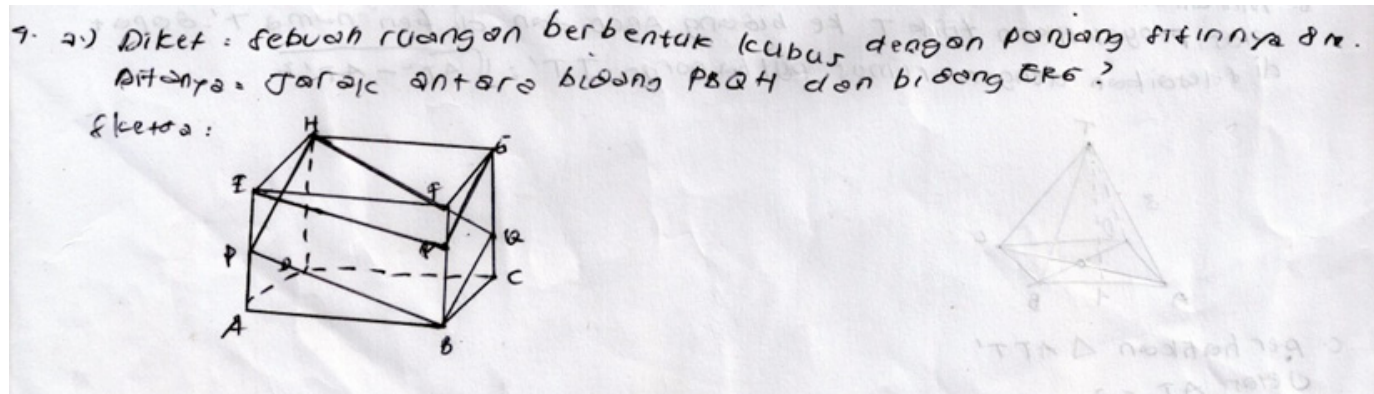

Figure 5. E-05 Work Results in Understanding Problem Number 4 A

The results of E-05's work in understanding problem number $4 \mathrm{~A}$ can be seen in Figure 5. The figure shows that E-05 was informed, shown, and sketched but incomplete. At this stage, E-05 is less precise in drawing a problem-solving plan. However, E-05 was able to write down the formula to be used but was less thorough in writing. The E-05 is able to perform calculations correctly, but does not draw final conclusions. At the stage of implementing the problem-solving plan, they are less able to carry out the problem-solving plan, are not precise in carrying out calculations, and do not write down the final conclusion. At the re-examining stage, students with low self-efficacy check again by researching/ rereading the steps taken but cannot use other methods. Students' problemsolving abilities will be summarized based on the stages of problem solving according to Polya, namely (1) understanding the problem, (2) planning problem solving, (3) implementing a problem-solving plan, and, (4) re-checking again. 
The findings of students' problem-solving abilities in terms of self-efficacy are summarized in table 2 .

\begin{tabular}{|c|c|c|c|c|}
\hline No. & Polya's stages & $\begin{array}{c}\text { Self-Efficacy } \\
\text { High }\end{array}$ & Self-Efficacy Moderate & Self-Efficacy Low \\
\hline 1 & $\begin{array}{l}\text { Understanding } \\
\text { the Problem }\end{array}$ & $\begin{array}{l}\text { Able to understand } \\
\text { problems by } \\
\text { explaining what are } \\
\text { known, asking, and } \\
\text { sketching pictures } \\
\text { correctly and } \\
\text { completely. }\end{array}$ & $\begin{array}{l}\text { Able to understand } \\
\text { problems by explaining } \\
\text { what are known, } \\
\text { asking, and sketching } \\
\text { pictures correctly and } \\
\text { completely. }\end{array}$ & $\begin{array}{l}\text { Be able to } \\
\text { understand } \\
\text { problems by } \\
\text { explaining what are } \\
\text { known, asking, and } \\
\text { sketching images } \\
\text { correctly but not } \\
\text { completely. }\end{array}$ \\
\hline 2 & $\begin{array}{l}\text { Planning } \\
\text { Troubleshooting }\end{array}$ & $\begin{array}{l}\text { Able to plan complete } \\
\text { problem solving by } \\
\text { drawing, explaining } \\
\text { steps, and writing } \\
\text { formulas that will be } \\
\text { used correctly and } \\
\text { completely. }\end{array}$ & $\begin{array}{l}\text { Able to plan problem } \\
\text { solving by drawing, } \\
\text { explaining steps, and } \\
\text { writing formulas that } \\
\text { will be used correctly } \\
\text { and completely. }\end{array}$ & $\begin{array}{l}\text { Be able to plan } \\
\text { problem solving by } \\
\text { drawing, explaining } \\
\text { steps, and writing } \\
\text { formulas that will be } \\
\text { used correctly but are } \\
\text { incomplete. }\end{array}$ \\
\hline 3 & $\begin{array}{l}\text { Carry out a } \\
\text { Problem-Solving } \\
\text { Plan }\end{array}$ & $\begin{array}{l}\text { Be able to carry out } \\
\text { the problem-solving } \\
\text { plan in accordance } \\
\text { with the plan, to } \\
\text { perform calculations, } \\
\text { and to write final } \\
\text { conclusions correctly } \\
\text { and completely. }\end{array}$ & $\begin{array}{l}\text { Be able to carry out } \\
\text { the problem-solving } \\
\text { plan according to } \\
\text { the plan, to perform } \\
\text { calculations, and } \\
\text { to write down } \\
\text { conclusions correctly } \\
\text { but incompletely. }\end{array}$ & $\begin{array}{l}\text { Less able to } \\
\text { implement problem- } \\
\text { solving plans, less } \\
\text { precise calculations. } \\
\text { Didn't write down } \\
\text { the final conclusions. }\end{array}$ \\
\hline 4 & $\begin{array}{l}\text { Examining } \\
\text { again }\end{array}$ & $\begin{array}{l}\text { Examining again } \\
\text { by counting down, } \\
\text { researching and } \\
\text { rereading the steps } \\
\text { that have been done } \\
\text { and concluding } \\
\text { correctly, and being } \\
\text { able to use other } \\
\text { methods. }\end{array}$ & $\begin{array}{l}\text { Examining again } \\
\text { by researching and } \\
\text { rereading the steps } \\
\text { that have been done, } \\
\text { but unable to use other } \\
\text { methods. }\end{array}$ & $\begin{array}{l}\text { Examining again } \\
\text { by researching and } \\
\text { rereading the steps } \\
\text { that have been done, } \\
\text { but unable to use } \\
\text { other methods. }\end{array}$ \\
\hline
\end{tabular}




\section{CONCLUSION}

The results showed that: (1) the MMP learning model was effective against problem-solving abilities, because a) more than $75 \%$ of the students in the MMP class achieved mastery, and b) the average TKPM score in the MMP class was better than the conventional class. (2) a) Students with high self-efficacy were able to understand problems, plan problem solving, implement problem-solving plans, and check back correctly and completely. b) Students with moderate selfefficacy are able to understand problems, plan problem solving, carry out problem solving plans with correct and complete, in re-checking they are unable to use other means. c) Students with low self-efficacy are able to understand problems and plan problem solving correctly but are incomplete, less able to carry out problem-solving plans, as well as in checking again unable to use other means. 


\section{REFERENCES}

Bandura, A. 2002. Self-Efficacy in Changing Societies. Cambridge: Cambridge University Press.

Dwiningrat, G. A. A., Suniasih, N. W \& Manuaba, I. B. S. 2014. “Pengaruh Model Pembelajaran Missouri Mathematics Project terhadap Kemampuan Pemecahan Masalah Matematika Siswa". E-Journal MIMBAR, 2(1).

Fauziah, A. \& Sukasno. 2015. “Pengaruh Model Missouri Mathematics Project (MMP) Terhadap Kemampuan Pemahaman dan Pemecahan Masalah Matematika Siswa SMA N 1 Lubuklinggau". Jurnal Ilmiah Program Studi Matematika STKIP Siliwangi Bandung, 4(1): 10-21.

Fuaddilah Ali Sofyan, “Implementasi HOTS Pada Kurikulum 2013". Jurnal Inventa, 1(1): 4-5.

Good, T.L. \& D.A Grouws. 1979. “The Missouri Mathematics Effectiveness Project: An Experimental Study in Fourth-Grade Classrooms". Journal of Educational Psychology, 71(3):355-362.

Lazakidou, G., Parasheva, F., \& Retalis, S. 2007. “The transitory phase to the attainment to self-regulatory skill in mathematical problem solving". International Education Journal, 8(1): 71-81.

Lee, Ngan H., Yeo, Darren J. H. S., \& Hong, Seek E. 2014. “A Metacognitivebased Instruction for Primary Four Students to Approach Non-Routine Mathematical Word Problems. ZDM Mathematics Education, 46: 465480. doi:10.1007/s11858-014-0599-6.

Lunenburg, F.C. 2011. “Self-Efficacy in the Workplace: Implications for Motivation and Performance". International Journal of Management, Business, and Administration, 14(1): 1-5.

Marnoko. 2011. “Perbedaan Model Pembelajaran Kooperatif Tipe Teams Games Tournament dan Model Pembelajaran Konvensional pada Hasil Belajar Ekonomi Mahasiswa". Jurnal Ilmiah Abdi Ilmu, 4(2).

McCoach, D. B. 2007. “Increasing Student Mathematics Self-Efficacy Through Teacher Training". Journal of Advanced Academics, 18(2): 278-312.

Michaelides, M. 2008. "Emerging Themes from Early Research on Self-Efficacy Beliefs in School Mathematics". Electronic Journal of Research in Educational Psychology, 6(1): 219-234. 
Mustaqim, M. 2015. “Model Pendidikan Karakter Terintegrasi Pada Pembelajaran Di Pendidikan Sekolah Dasar". Elemtary, 3(1).

Mukhid, A. 2009. “Self-Efficacy (Perspektif Teori Kognitif Sosial dan Implikasinya terhadap Pendidikan)". Tadris, 4(1): 108-122.

National Council of Teachers of Mathematics. 2000. Principles and standards for school mathematics. Reston, VA: Author.

Nicolaidou, M. dan Philippou, G. 2004. “Attitudes Towards Mathematics, SelfEfficacy and Achievement in Problem Solving". European Research in Mathematics Education III Thematic Group 2. University of Cyprus.

Noor, N. 2020. “Peningkatan Kemampuan komunikasi Matematis peserta Didik Melalui Open Ended Problem. Elementary". 8(2): 209-224.

Pimta, S., Tayruakham, S., \& Nuangchalerm, P. 2009. “Factors Influencing Mathematic Problem-Solving Ability of Sixth Grade Students". Journal of Social Sciences, 5 (4): 381-385.

Polya, G. 1985. How to Solve It. A New Aspect of Mathematical Methods. New Jersey: Pearson Education, Inc.

Savitri, S.N., Rochmad., \& Arief, A. 2013. “Keefektifan Pembelajaran Matematika Mengacu pada Missouri Mathematics Project terhadap Kemampuan Pemecahan Masalah". Unnes Journal of Mathematics Education, 2 (1): 28.

Schunk, D. H. \& Hanson, A. R. 1985. “Peer Model: Influence on Children's Self Efficacy and Achievement". Journal of Educational Psychology, 77: 313322.

Schunk, D.H. 1981. “Modelling and Attributional Effect on Children Achievement: A Self Efficacy Analysis". Journal of Educational Psychology, 73: 93-105.

Sugiyono. 2013. Metode Penelitian Kombinasi (Mixed Methods). Bandung: Alfabeta.

Tzohar-Rosen, M., \& Kramarski, B. 2014. “Metacognition, motivation and emotions: Contribution of self-regulated learning to solving mathematical problems". Global Education Review, 1(4): 76-95.

Westwood, P. 1996. Effective Teaching. Australian Journal of Teacher Education, 21(1): 66-84.

Widdiharto. 2004. Model-Model Pembelajaran Matematika SMP. Yogyakarta: PPPG Matematika. 